\title{
ANALYSIS OF LEGAL SUPERVISION IN PREVENTING CRIMINAL PRACTICES AND CAPITAL MARKET VIOLATIONS
}

\author{
Wandi Subroto \\ Sekolah Tinggi Ilmu Hukum Rahmaniyah Sekayu \\ Email: wandi.stihr@gmail.com
}

\begin{abstract}
This study aims to analyze legal supervision in preventing criminal practices and capital market violations. The type of research used in this study is the juridical-normative method, namely research on a legal principle contained in positive law that has been applied in Indonesia. The positive law in question is the regulation that regulates Capital Market Number 8 of 1995, the Law on the Financial Services Authority, and other Implementing Regulations. The types of legal sources used in this study are secondary legal sources and tertiary legal sources collected using the library research method. The research analysis used qualitative methods which were analyzed using a sociological approach. Qualification of forms of criminal acts Law no. 8/1995 concerning the Capital Market is regulated in Article 103 paragraph (1), Article 104, Article 106 and Article 107. As for criminal acts in the form of violations, it is regulated in Article 103 paragraph (2), Article 105 and Article 109. The forms of sanctions for violations are divided into: administrative sanctions, civil sanctions, and criminal sanctions.
\end{abstract}

Keywords: Capital Market, Law, Crime, Violation.

\section{A. INTRODUCTION}

The success of the national development program in accordance with the mandate of Pancasila and the 1945 Constitution in order to create a decent living for the community, this is determined by the independence of the nation to sustainably carry out national economic development activities by relying on the strength of the community, the participation of the people who take part in the development financing program (Pakpahan et al., 2019). Through justifiable management of the state budget (APBN), legal certainty for investors and the commitment made by the government in regulating the management of the financial sector that is professional, honest and accountable (transparency) (Sofyan, 2019).

The main focus of national development is for the welfare of the people equally, improving the quality of human resources by utilizing technology and science. One of the products of national development is the development of the capital market, the development of the capital market has had a significant impact on economic development and trade (Junaedi, 2020; Pakpahan et al., 2020)). The capital market can be understood based on the explanation of Law Number 8/1995 concerning the Capital Market, in article 1 paragraph (15) it is stated that Go Public is a securitie offering activity which is used by issuers to sell securities to the public based on procedures in accordance with the law and implementing regulations.

The capital market has a strategic role for the business world, one of which is as a place of investment. Where investors can invest in several companies in the capital market, for example through the purchase of securities or shares traded in the capital market. Efforts made by the government greatly impact on market perceptions (Tlokonder et al., 2021). This 
has an impact on investor confidence to invest in Indonesia because it has been given legal protection. Based on Law Number 8/1995, it is necessary to regulate the disclosure of any information held by a company if the company is to offer its effects on the capital market (Radinda et al.,2020). Such information can be in the form of information regarding the state of its business or company, financial condition of the company, legal aspects that exist or are currently happening within the company, company management, company assets and others that are material and related to the public (Asril, 2019). The number of stock and mutual fund investors in the Indonesian Capital Market is presented in the following figure:

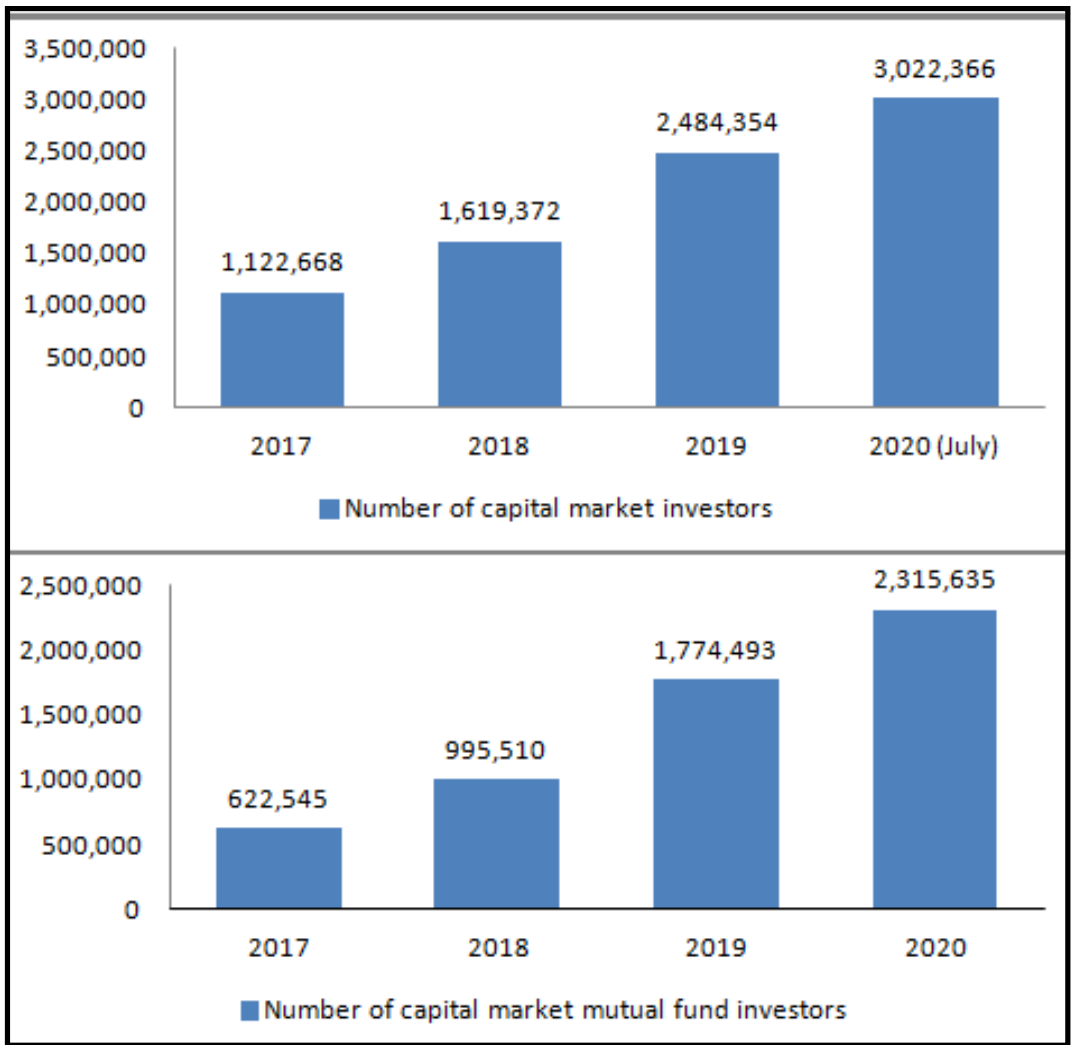

Figure 1. Comparison of Stock and Mutual Fund Investors in the Indonesian Capital Market (2017-2020 Period)

\section{Source: KSEI}

Economic development is progressing rapidly, but there is also economic instability that can open up opportunities for fraud for certain parties. For example, fraud in the capital market is in the form of market manipulation, which is an act that gives a false picture of an active trade, the price of a security, and pseudo transactions. For example, the Supreme Audit Agency (BPK) found that there were 14 findings containing 29 problems obtained from the results of the inspection of the capital market sector supervision during the 2018-2020 period. These problems include 16 problems regarding the weakness of the internal control system and 13 non-compliance with applicable regulations. A significant problem is related to the weakness of internal control. The Supreme Audit Agency considers this to have an impact on the weak accountability of the process of handling indications of violations of the Capital Market Law and capital market crimes, including in this case mutual funds that are considered to have violated these provisions (Shara, 2021).

The Indonesian capital market already has a legal instrument, Law Number 8/1995 concerning the Capital Market and its implementing regulations, but this regulation is still not 
sufficient because there are still practices that have not been regulated in the legislation (Mochtar, 2021). Even though the Financial Services Authority as an institution that acts as the organizer/executor, builder and supervisor of the Indonesian Capital Market always makes regulations that can meet the needs of the Capital Market, but adequate legal instruments are not a guarantee of legal protection and certainty, because the protection and legal certainty, because legal protection and certainty will be achieved if the legal instruments that have been made will be enforced by the Financial Services Authority (Azizah, 2017). If this is not done, then it is impossible for the Capital Market to provide maximum support for the development of the national economy in general and the development of the financial sector in particular. For example, the issue of insider trading can make investors lose confidence in the Capital Market, because of course every investor has the desire that the funds invested are guaranteed, especially in terms of certainty and law enforcement (Mubarokhah, 2020).

Another crime is insider trading, namely parties affiliated with the issuer, this allows several parties to have important information that has an influence on the price of an issuer's share on the stock exchange. By the insider (insider) material information that is still confidential, is used to carry out the transaction, with the intention of obtaining profit for himself (Baker et al.,2020). The possibility of insider trading crimes can be seen from the activities of insiders to conduct a transaction on the company's securities, it can be seen from either the increase or decrease in the price and the volume of suspected (unnatural) trading (Al-Awadhi et al.,2020). As well as from the price and volume whose material information has not been announced to the public.

In the Capital Market Law, three types of criminal acts have been regulated, namely: 1) fraud; 2) market manipulation; and 3) insider trading. In general, it is known that the stolen goods are not real, but information, besides the perpetrators are also intellectuals and the proof also tends to be difficult. Furthermore, Law Number 8/1995 is complemented by criminal regulations with fairly severe criminal threats, but some criminal cases are very rarely resolved by the Criminal Justice System by the Financial Services Authority as an agency that has the authority to develop, regulate and supervise the capital market at the same time. criminal investigators in the Capital Market. In order to carry out law enforcement against violations of laws and regulations in the Capital Market sector, in accordance with Article 100 and Article 101 of Law Number 8 of 1995 concerning Capital Markets, the Financial Services Authority which has obtained the transfer of authority from Bapepam as the supervisory institution of the Capital Market sector, is given the authority to conduct an examination and investigation of a violation of the laws and regulations in the Capital Market sector (Phan \& Narayan).

Regarding this problem, the Financial Supervisory Agency recommends that the chairman of the Board of Commissioners of the Financial Services Authority improve the Securities Alert Review Guidelines and the Off-Site Monitoring Results Follow-up Guidelines which are related to the entire authority of the Financial Services Authority, this also applies to mutual funds and refunds. customer. The investors are indirectly victims, in this case the investors do not experience any visible physical injuries. But for ordinary investors, for example, they don't understand the impact that can be caused, so they don't have a problem if the information is used by insiders for trading, even the public does not 
think that the use of this information is considered not to cause investors to lose money (lose their money). There will be an impact caused, namely in the form of the loss, which is real and can be calculated. Whereas the situation that befell the investor community, in this case is the theft carried out by the perpetrators where they did not steal from the public, but the perpetrators took advantage of the situation by using information with their backs on other investors, who should have the same opportunity.

Because of this, investors must be more careful in any risks that arise and at the same time minimize them. Several cases of crime in the capital market are fraud cases labeled as investments. Stupid investments such as: 1) meMiles, which has a turnover of up to IDR 750 billion. In a period of 8 months, this company got about 240,000 members, the way this company works is to invite new members to join by placing ads. 2) GIG Tissue investment product, this company has succeeded in defrauding 3,131 members, this investment product was issued by Bintara Eximindo Ltd. Engaged in advertising marketing for products in the form of tissue; 3) The Satria Investment Global (SIG) fraud, this case lasted from 2012 to 2019 but there were no significant developments. This case has deceived about 700 victims who live in the city of Palembang with a total loss of IDR 67 billion; and 4) Investment of MGI Ltd. This capital market investment fraud reached a total loss of IDR 400 billion for the victim, the suspect is a Malaysian citizen who has not been caught because he is abroad, the modus operandi of the perpetrator is to invite the victim to buy mobile phone credit. Because of this description, the author is interested in researching legal supervision to prevent bad practices in the Indonesian capital market.

\section{B. METHOD}

The type of research used in this study is the juridical-normative method, namely research on a legal principle contained in positive law that has been applied in Indonesia. The positive law in question is the regulation that regulates Capital Market Number 8 of 1995, the Law on the Financial Services Authority, and other Implementing Regulations. The types of legal sources used in this study are secondary legal sources and tertiary legal sources which were collected using the library research method. The research analysis used qualitative methods which were analyzed using a sociological approach.

\section{RESULT AND DISCUSSION}

\section{Qualification of Capital Market Crime Forms}

The number of crimes and violations that occur in the world of capital markets can be caused by several factors, including the weak efforts of existing policymakers and regulations. The Financial Services Authority has the authority to review the law which includes law enforcement and protection, this is very important because the capital market is a trusted institution that acts as an intermediary to connect related and interested parties. Proving crimes in the capital market by perpetrators tends to be difficult because they are administrative in nature related to the submission of certain reports to the Financial Services Authority or to the public, violations can also be technical in nature related to issues of licensing, approval and registration with the Financial Services Authority.

Based on article 110 paragraph (1) of the Capital Market Law, the violations are: 1) 1) According to Article 103 paragraph (2) of the Capital Market Law: Every activity carried out 
in the capital market must obtain a permit from BAPEPAM; 2) According to Article 105 of the Capital Market Law: Affiliated parties may not receive compensation in any form that is considered to be able to influence the relevant affiliated party in carrying out activities related to Mutual Funds; and 3) According to Article 109 of the Capital Market Law: BAPEPAM is authorized to conduct an examination of any party in the capital market suspected of violating the Act or its implementing regulations. There are several patterns of violations that often occur, namely individual, group violations and those carried out on the basis of orders or the influence of other parties. Public companies and issuers as well as parties who have strategic positions in the company are various parties that are possible to commit violations in the capital market. In addition, professionals consisting of Investment Advisors, Investment Managers, Legal Consultants, Public Accountants, and Notaries are also parties that have the potential to commit fraud. Crime in the capital market is broadly described in the following figure:

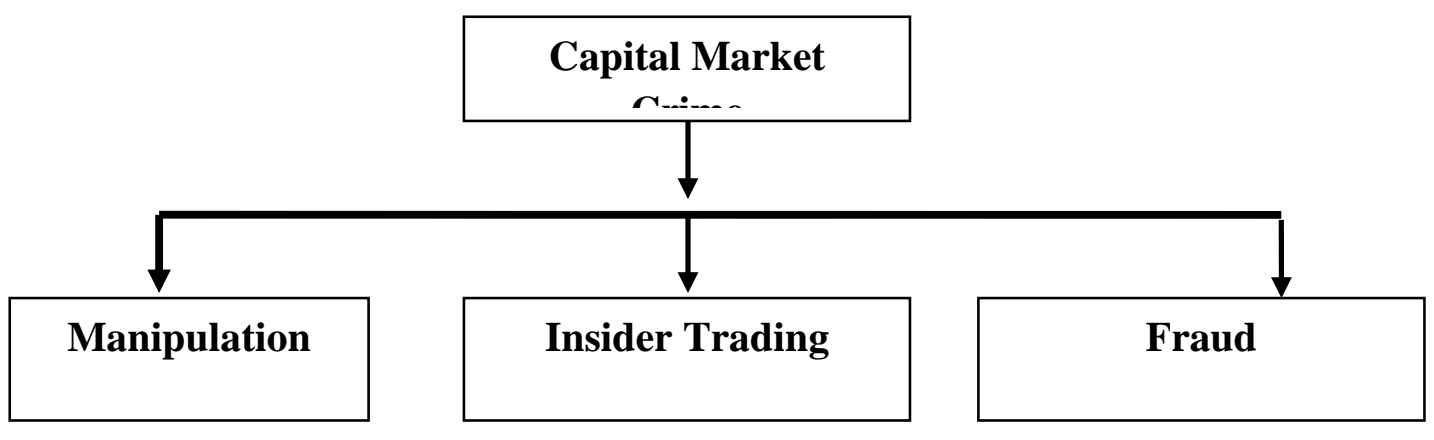

Figure 2. Crime in the Capital Market

Source: data proceed

Crimes in the capital market include Market Manipulation. Based on Article 91 of the Capital Market Law, what is meant by manipulation is that each party is prohibited from creating a simple and potentially misleading picture regarding trade, both direct and indirect trading. Market activity on this exchange is described in the following figure:

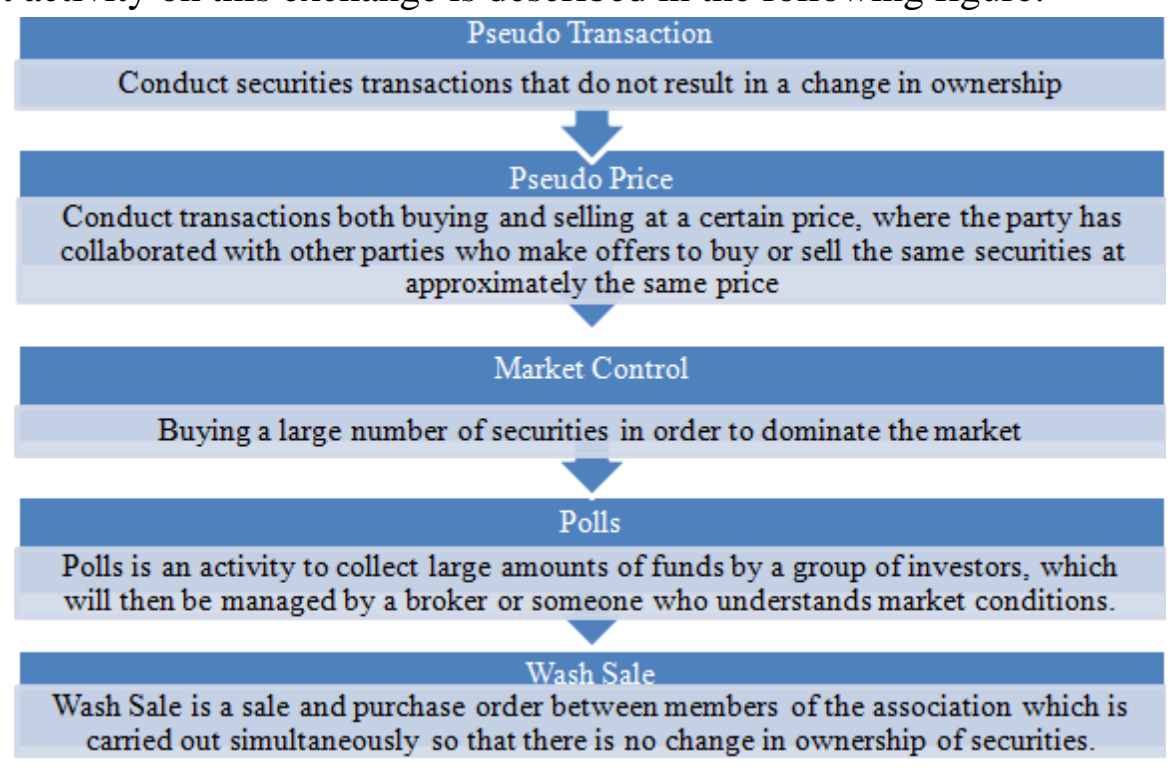

Figure 3. Manipulating Activities in the Capital Market

Source: Data Proceed 
In addition, market manipulation patterns can also occur by 1) spreading false information related to issuers that can potentially drop the price of securities in the stock exchange; 2) Disseminate incomplete and potentially misleading information. Because information is a very important guide for investors because it can affect the price of an issuer.

Some of the market manipulation modes include: 1) Pseudo Transaction, this transaction is carried out to obtain a foreign portion from an issuer. In the stock exchange, the issuer's shares have been sold out, but because the shares of the founders and the main shareholders are still being traded, the shares can still be bought. The purpose of this mode is that the founder obtains a note from a foreign transaction and has obtained a permit to be sold; 2) Price formation, this is done by lowering and increasing the total price so that price formation can be determined. Ways of price formation can be done, namely by way of the investor instructing his acquaintances to make a transaction both buying and selling to one broker while he himself also makes a transaction order to another broker at a price that has been formed, the purpose of this is usually to play the budget. Price formation in closed transactions (on the crossing board) is also carried out because the prices requested by customers as well as those that occur on the regular experience quite significant changes.

The second capital market crime is insider trading, this crime has been regulated in Law Number 8 of 1995 concerning the Capital Market. In articles 95-99 then the legal sanctions are regulated in articles 103-110 (criminal sanctions) and articles 102 (civil sanctions). Furthermore, Ministerial Regulation No. 46/1995 which gives the Financial Services Authority the authority to carry out supervision, investigation and prosecution. The object of crime in insider trading is in the form of material information and is still confidential (not yet open to the public) so that insiders use these opportunities for their own interests and benefits, both individually and collectively. The Financial Services Authority, in this case, has the authority to impose sanctions, both criminal sanctions in the form of imprisonment (maximum 10 years and a maximum fine of IDR 15 billion) as well as administrative sanctions against parties who have been proven to have violated the Capital Market Law. This authority is contained in Law Number 8 of 1995 concerning Capital Markets in Articles 100 and 1001 and has also been further regulated as in Government Regulation Number 46 of 1995 concerning Procedures for Examination in the Capital Market Sector.

The third capital market crime is fraud. Fraud as described in Article 90 letter $\mathrm{c}$ of the Capital Market Law is making an untrue statement regarding material facts or not disclosing material facts so that the statements made are not misleading regarding the circumstances that occurred at the time the statement was made with the intention of benefiting or avoiding harm to oneself or the other party. others or with the purpose of influencing another Party to buy or sell Securities. This prohibition is aimed at all parties involved in securities trading, even participating in fraud is included in this provision. In article 378 of the Criminal Code (KUHP), it is explained that fraud is an act to benefit oneself or others by: 1) Against the law; 2) Using a false name or false dignity; 3) Deceit; 4) A series of lies; and 5) Persuade another person to hand over something to him, or to give debt or write off receivables. By taking into account the provisions stipulated in the Criminal Code, the Capital Market Law provides several specifications regarding fraud, which are limited to securities trading activities, including offering, buying and or selling securities that occur within the framework of a 
public offering or occur on the stock exchange or outside the stock exchange for the securities of the issuer or public company.

\section{Other Actions That Can Be Categorized as Criminal Acts in the Capital Market Sector}

In addition to the forms of criminal acts that have been mentioned, the Capital Market Law has categorized a number of other actions in the capital market sector which are categorized in the form of actions that are threatened by criminal law, including: 1) Any party who does not have a permit or registration and carries out activities in the market. capital; 2) Issuers who make public offerings but do not submit registration statements, or their registration has not been deemed effective by BAPEPAM; 3) Investment managers and affiliated parties who receive compensation from other parties in any form, directly or indirectly, to purchase or sell securities; 4) Everyone who commits fraud, misleads, destroys, removes, alters, obscures, hides or falsifies records from parties has obtained permission, approval and registration from BAPEPAM (Article 107).

Violations in the capital market sector have their own characteristics that are different from other types of violations. Violation of the laws and regulations in the capital market sector is a matter that is prone to be carried out by the parties involved in the capital market. Violations in the capital market sector are violations of a technical administrative nature. There are 3 (three) patterns of violations that commonly occur, namely: 1) Violations committed by individuals; 2) Violations committed in groups; and 3) Violations committed based on orders from other parties. As it is known that capital market crimes have a considerable influence, especially on potential investors and investors on the development of the capital market as a whole. Due to the weakness of regulations regarding capital market crimes, it is advisable to tighten the supervision of capital market traffic, so that transactions suspected of containing crimes should be tightened. in a cross-capital market can be detected early.

\section{Forms of Prevention and Law Enforcement against Crimes in the Capital Market Sector}

In general, law enforcement can be interpreted as the act of applying certain legal instruments to impose legal sanctions to ensure compliance with the stipulated provisions. The existence of the Indonesian capital market plays a very important role in the development of the Indonesian economy, so it is regulated in a special regulation, namely Law No. 8 of 1995 concerning the Capital Market (Capital Market Law) and various regulations of the Financial Services Authority. This special arrangement aims to ensure that activities in the Capital Market can run consistently and according to principles for all capital market participants and that there are no violations and criminal acts, so that the objectives of establishing the capital market can be realized. Over the past 32 years, the existence of the Indonesian capital market has continued to increase, with many business players starting to invest in the Capital Market. Unfortunately, in line with the development of the capital market, violations and criminal acts of the capital market are also increasing.

There is an impression that this is caused by weak law enforcement, which could be due to capital market laws and regulations that are lagging behind the development of capital 
market business, weak law enforcement institutions in carrying out law enforcement or lack of professionalism of law enforcement officers themselves, that is what needs to be done. looking for a solution. How law enforcement can be applied to create a safe and trustworthy capital market for the public, especially investors. The Stock Exchange, as the institution that organizes the implementation of securities trading, if in conducting a securities trading transaction finds a violation, which indicates a violation of a criminal nature, this institution will submit the violation to Bapepam for examination and investigation. The authority to investigate each case (violation of criminal laws and regulations) for Bapepam is granted by the Criminal Procedure Code as stated in the provisions of Article 6 (paragraph 1) letter (b). which states: Investigators are certain civil servants who are given special authority by law. This authority is a manifestation of Bapepam's function as a supervisory agency.

If there is a violation of capital market laws or provisions in other capital market fields, Bapepam as an investigator will conduct an examination of the party committing the violation, until if it is proven that it will impose sanctions on the perpetrator. The stipulation of sanctions will be given or decided by the chairman of Bapepam after receiving input from the examination and investigation division of Bapepam. If those who are subject to sanctions can accept the decision. Then the sanctioned party will carry out everything that has been set by Bapepam. The problem will continue if the sanctions that have been set cannot be accepted or are not implemented, for example the fine set by Bapepam is not fulfilled by the party suspected of having committed a violation, it will proceed to the prosecution stage, by submitting the case to the Prosecutor's Office as the agency responsible for the violation. authorized to prosecute. Bapepam's position is described in the following figure:

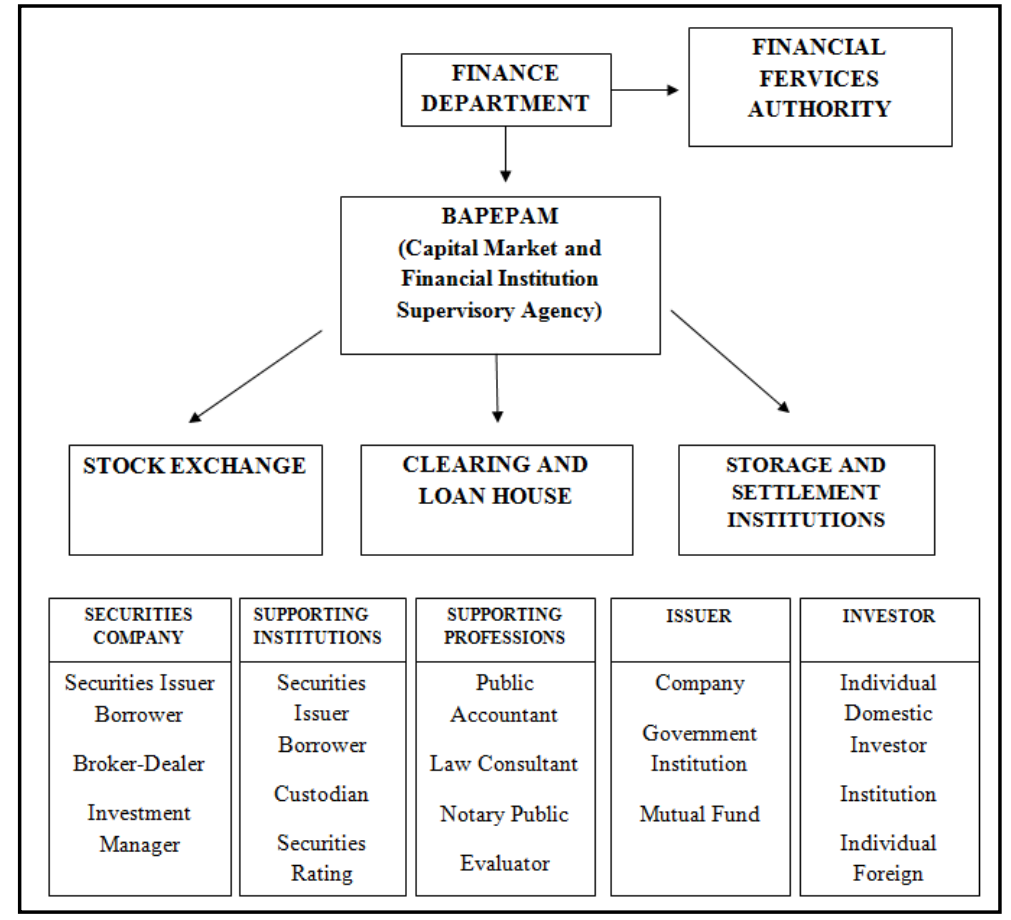

Figure 4. BAPEPAM's Position in the Capital Market Supervisor

Source: Data Proceed

Law number 8/1995 concerning the Capital Market expressly stipulates requirements and sanctions for capital market players, both for professionals and supporting professions, securities companies, self-regulatory organizations (Stock Exchanges, Clearing Guarantee 
Institutions, Depository and Settlement Institutions). as well as issuers. It is hoped that law enforcement in the capital market can show more authority so as to create a high sense of trust in the hearts of investors. In the implementation of the capital market, law enforcement is very important to give confidence to investors in conducting their business. As regulated in Article 100 of the Capital Market Law, BAPEPAM has the authority to conduct an examination of any party suspected of committing or being involved in a violation of the Capital Market Law and or its implementing regulations. With this authority, BAPEPAM can collect information or other necessary information as evidence of violations of capital market regulations.

After the formation of the Financial Services Authority, the transfer of functions, duties and authorities of the capital market sector and other financial service institutions to the Financial Services Authority is a juridical implication of the promulgation of Law no. 21 of 2011 concerning the Financial Services Authority. The efforts referred to are specifically carried out through the establishment of a directorate within the OJK institution which previously did not exist or at least was not an independent function within the BAPEPAM institution and through the expansion of the supervisory function that had existed previously. There are three types of sanctions applied in law number 8 of 1995 concerning the capital market which are described in the following table:

Table 1. Sanctions for Violating Capital Market Laws

\begin{tabular}{|c|l|}
\hline Type of Sanction & \multicolumn{1}{|c|}{ Explanation } \\
\hline \multirow{5}{*}{ Administrative Sanctions } & $\begin{array}{l}\text { Administrative sanctions are sanctions imposed by BAPEPAM } \\
\text { on parties deemed to have violated the laws and regulations in } \\
\text { the capital market sector. Parties that may be subject to } \\
\text { sanctions are: 1) Parties that obtain permits from BAPEPAM; 2) } \\
\text { Parties that obtain approval from BAPEPAM; and 3) The party } \\
\text { registering with BAPEPAM. }\end{array}$ \\
\hline Civil Sanctions & $\begin{array}{l}\text { Civil sanctions are mostly based on the Limited Liability } \\
\text { Company Law where issuers or public companies must also } \\
\text { comply. The Limited Liability Company Law and the Capital } \\
\text { Market Law provide provisions that allow shareholders to file a } \\
\text { civil lawsuit against any manager or commissioner of a } \\
\text { company whose actions or decisions cause losses to the } \\
\text { company. }\end{array}$ \\
\hline \multirow{5}{*}{ Criminal sanctions } & $\begin{array}{l}\text { The Capital Market Law (articles 103-110) threatens any party } \\
\text { found to have committed a crime in the capital market sector to } \\
\text { be subject to imprisonment ranging from one to ten years. The } \\
\text { threat of criminal penalties and heavy fines can be considered } \\
\text { reasonable considering that securities trading activities involve } \\
\text { many investors and a very large amount of money. }\end{array}$ \\
\hline
\end{tabular}

Source: Data Proceed

With these various functions, Bapepam can realize the goal of creating an orderly and efficient capital market activity that can protect the interests of investors and the public. In carrying out its law enforcement function, Bapepam is proactive if there are indications of 
violations of capital market laws and regulations. By conducting examinations, and or investigations, which are based on reports or complaints from capital market actors, the data is analyzed by Bapepam and the results are used for public consumption by reporting through the mass media.

Since 1997, Bapepam has conducted periodic press releases to the public, including through mass media and internet media. The Press Release issued by Bapepam is a form of publication and accountability to the public regarding the condition and existence of a company, as well as the public's need for other capital market information, for example, if there is a new legislative policy from Bapepam. In addition, the policy to always make reports to the public through press releases is a manifestation of the principles of honesty and openness (transparency) adopted by this capital market supervisory agency.

Settlement of disputes in violation of the capital market sector is carried out through litigation and non-litigation channels. The use of non-litigation channels is carried out by alternative dispute resolution. Settlement of this dispute has been regulated by law number 1999 concerning Arbitration which came into force on 1999. Settlement of Indonesian capital market disputes outside of litigation can be pursued through the Indonesian Capital Market Arbitration Board (BAPMI). BAPMI. Dispute resolution that occurs outside the court is more widely used and chosen because of many factors including being more efficient in terms of time, costs incurred, easier procedures and there is a guarantee of confidentiality.

\section{CONCLUSION}

Based on the results of the analysis of legal materials, it can be concluded that criminal acts and violations in the Capital Market are broadly categorized into: 1) Market Manipulation; 2) Fraud; and 3) Insider Trading. Meanwhile, Capital Market Violations are administrative violations, both regarding approvals, licensing, and registration with BAPEPAM. Qualification of forms of criminal acts Law no. 8/1995 concerning the Capital Market is regulated in Article 103 paragraph (1), Article 104, Article 106 and Article 107. As for criminal acts in the form of violations, it is regulated in Article 103 paragraph (2), Article 105 and Article 109. The forms of sanctions for violations are divided into: administrative sanctions, civil sanctions, and criminal sanctions.

\section{REFERENCES}

Al-Awadhi, A. M., Alsaifi, K., Al-Awadhi, A., \& Alhammadi, S. (2020). Death and contagious infectious diseases: Impact of the COVID-19 virus on stock market returns. Journal of behavioral and experimental finance, 27, 100326.

Asril, J. (2019). Kejahatan dalam Bidang Pasar Modal di Era Globalisasi dan Model Hukum Untuk Menghadapinya. Jurnal Ilmiah MEA (Manajemen, Ekonomi, \& Akuntansi), 3(3), 248-258.

Azizah, A. (2017, October). Punishment Against the Perpretrator of Insider Trading (Comparation Between Indonesia Law and Singapore Law). In International Conference on Law, Governance

Baker, S. R., Bloom, N., Davis, S. J., Kost, K., Sammon, M., \& Viratyosin, T. (2020). The unprecedented stock market reaction to COVID-19. The review of asset pricing studies, 10(4), 742-758. 
Dewi Astutty Mochtar, D. A. R. (2021). Investors'legal Protection Against Insider Trading in Capital Market in Indonesia. Journal of Southwest Jiaotong University, 56(4).

Junaedi, A. (2020). Tindak Pidana Insider Trading Dalam Praktik Pasar Modal Indonesia. Media Iuris, 3(3), 299-318.

Mubarohkah, S. L. (2020). Insider Trading Dalam Prespektif Hukum Pidana di Indonesia. Dinamika: Jurnal Ilmiah Ilmu Hukum, 26(3), 372-380. and Globalization.

Pakpahan, E. F., Kurniawan, E., Candra, K., \& Yanti, S. (2020). Peran dan Kewenangan Otoritas Jasa Keuangan (OJK) Terhadap Keamanan Transaksi Di Pasar Modal. Ius Civile: Refleksi Penegakan Hukum dan Keadilan, 4(1).

Pakpahan, E. F., Prisilla, V., Dicky, D., \& Malau, Y. A. (2020). Peran Dan Kewenangan Profesi Penunjang Pasar Modal (Notaris) Dalam Menghadapi Era Globalisasi. JCH (Jurnal Cendekia Hukum), 5(2), 323-332.

Pakpahan, E. F., Sianipar, B. D., Angkasa, J., Sianturi, V. R., \& Hulu, S. R. (2019). Peran Pemerintah dalam Mitigasi Kejahatan Pasar Modal Indonesia. Journal of Education, Humaniora and Social Sciences (JEHSS), 2(1), 104-118.

Pakpahan, E. F., Wijaya, S. F., Fortunata, A., Chang, J., \& Muhammad, H. (2019). Benturan Kepentingan bagi Konsultan Hukum dalam Kejahatan Pasar Modal. Jurnal Ilmiah Penegakan Hukum, 6(2), 78-85.

Phan, D. H. B., \& Narayan, P. K. (2020). Country responses and the reaction of the stock market to COVID-19-A preliminary exposition. Emerging Markets Finance and Trade, 56(10), 2138-2150.

Radinda, F. A. M., Massora, M. A. N., \& Fathonah, R. A. (2020). Praktik insider trading sebagai bentuk pelanggaran prinsip keterbukaan informasi dalam pasar modal di Indonesia. Jurnal Cakrawala Hukum, 11(1), 41-49.

Shara, M. C. P. (2021). Studi Komparasi Pendekatan Hukum Pada Pengaturan Insider Trading Dalam Kaitannya Dengan Penegakan Di Dunia Pasar Modal. Jurnal Litigasi (e-Journal), 22(1), 39-70.

Sofyan, T. (2019). Analisis Yuridis Sistem Pengawasan terhadap Kejahatan Pasar Modal. Recital Review, 1(1), 13-31.

Tolokonde, J., Anshar, A., \& Imam, W. Z. (2021). Kebijakan Hukum Pidana Terhadap Praktik Insider Trading Sebagai Kejahatan Bisnis Di Bidang Pasar Modal. Hermeneutika: Jurnal Ilmu Hukum, 5(2). 